\title{
Problemer i det tværfaglige, tværorganisatoriske, tværsektorielle samarbejde i psykiatrien
}

\author{
Elisabeth Naima Mikkelsen, Anne Petersen \& Anne Reff Pedersen
}

I denne artikel præsenteres et kritisk perspektiv på de ændrede organisationsformer, der særligt ses inden for den offentlige sektor. Her samarbejdes der i højere grad om kerneopgaven på tværs af faggrupper, organisationer og sektorer, men mange tiltag gennemføres ofte på baggrund af besparelser, hvor mere samarbejde bliver svaret på effektivisering af den offentlige sektor. I denne artikel vises, hvilke dynamikker der er i spil, når det tværfaglige, tværorganisatoriske og tværsektorielle samarbejde ikke fungerer. I forhold til nærværende tema om tværfaglighed og samarbejde ønskes der i artiklen at skabe opmærksomhed om nogle af de typiske faldgruber, der kan opstå ved organisering af samarbejde på tværs.

\section{Indledning}

I Danmark har vi socialpsykiatrien og behandlingspsykiatrien. Socialpsykiatrien hører under kommunerne, mens behandlingspsykiatrien hører under regionerne. Mennesker med svære sindslidelser og andre komplekse sociale problemstillinger er i deres behandlingsforløb ofte i kontakt med både socialpsykiatrien og behandlingspsykiatrien. Mens behandlingspsykiatrien står for selve den medicinske behandling, er socialpsykiatrien ansvarlig for støtte til de sindslidende - både af praktisk og social karakter. Da både de socialfaglige medarbejdere i socialpsykiatrien og de sundhedsfaglige medarbejdere i behandlingspsykiatrien fungerer som vigtige aktører $\mathrm{i}$ de sindslidendes behandlings- og støtteforløb, har et godt samarbejde mellem disse faggrupper stor betydning for de sindslidendes ople- velser af et sammenhængende forløb samt deres psykiske og sociale velbefindende. En række undersøgelser (Johansen m.fl. 2012; Kistrup m.fl. 2009; Madsen m.fl. 2011; Mikkelsen m.fl. 2013; Rådgivende Sociologer 2012), som er blevet udarbejdet i de senere år, har dog dokumenteret, at det tværsektorielle samarbejde mellem socialpsykiatrien og behandlingspsykiatrien flere steder i Danmark er præget af alvorlige problemer.

Undersøgelserne peger specifikt på en række barrierer for det tværgående samarbejde i psykiatrien. F.eks. udgør en væsentlig barriere, at der mangler fokus på og prioritering af det tværgående samarbejde mellem sektorerne (Bengtsson 2011), særligt på ledelsesniveau, da koordineringen af patienters behandlingsforløb kræver ledelse på tværs af professioner, organisa- 
tioner og sektorer (Holm-Petersen \& Buch 2014). Formelt set er samarbejdet reguleret af sundhedsaftaler mellem region og kommune (se eksempelvis Region Hovedstaden 2010; Region Hovenstaden 2014), men undersøgelser viser, at medarbejdere i begge sektorer har begrænset kendskab til aftalerne, og at de derfor ikke spiller en særlig central rolle i den daglige koordinering på tværs af sektorer (Johansen m.fl. 2012; Kistrup m.fl. 2009).

Med udviklingen på det psykiatriske område, i form af nedlagte sengepladser og kortere indlæggelsestid, foregår der en opgaveglidning fra behandlingspsykiatrien til socialpsykiatrien, hvor de psykiatriske hopitaler har indskrænket sig til primært at tilbyde medicinsk behandling og har overladt terapi og rehabilitering til de socialpsykiatriske tilbud (Madsen m.fl. 2011). Som følge af denne udvikling udpeges en af de største barrierer til at være kulturforskelle mellem de fagligheder, som arbejder i psykiatriens to sektorer, og som fører til, at begreber som 'sygdom', 'behandling' og 'rehabilitering'/'recovery' defineres forskelligt blandt de sundhedsfaglige og socialfaglige medarbejdere, som arbejder i hhv. behandlingsog socialpsykiatrien (Bengtsson 2011). Johansen m.fl. (2012) konkluderer således:

"I den danske litteratur peges der på, at de centrale barrierer er kulturelle snarere end strukturelle. Det vil sige, at de handler om professionel identitet og om forskellige opfattelser af sygdom og behandling snarere end om organisatoriske og lovmoessige barrierer" (Johansen m.fl. 2012, 7).

I tråd hermed ligger en anden stor barriere for det tværgående sektorsamarbejde i form af traditioner for silotænkning og afdelingsfokus, hvor der ikke er tradition for, at man blander sig i de andre afdelingers/ organisationers anliggender og slet ikke på tvær af sektorer (Seemann m.fl. 2012). Der hersker således et såkaldt "ude af øje ude af sind-perspektiv på patienter" (Holm-Petersen \& Buch 2014,8$)$ blandt de ansatte i sundhedssektoren. Endnu en massiv barriere for sektorsamarbejdet er, at medarbejderne oplever manglende indsigt i og viden om den anden sektors arbejde, faglighed og organisering, og det kan derfor være svært at forstå de disponeringer, der foretages af medarbejderne i den anden sektor (Mikkelsen m.fl. 2013; Rådgivende Sociologer 2012). Denne oplevelse af manglende viden om 'de andre' er med til at øge afstanden mellem de frontmedarbejdere, der skal koordinere og samarbejde.

Megen af den danske litteratur om problemerne i det tværgående sektorsamarbejde anlægger således et professionsperspektiv for at forklare, at samarbejdsproblemerne handler om en professionskamp mellem sundhedsfagligt og socialfagligt personale. Det argumenteres, at mødet mellem forskellige psykiatriske organisationer og fagkulturer skal forstås som en forhandling af forskellige verdensbilleder, hvor forskellige billeder af 'os og dem' kommer i spil (Bengtsson 2011; Holm-Petersen \& Buch 2014; Johansen m.fl. 2012; Madsen m.fl. 2011). Også kaldet 'paradigmekampen' fremhæver dette perspektiv, at stridighederne udspringer af forskellige opfattelser af psykisk sygdom og behandling. Er psykisk sygdom en biomedicinsk tilstand, der primært skal behandles med medicin? Eller er det en bio-psyko-social lidelse, som skal afhjælpes gennem professionel støtte, hvor der arbejdes recovery-orienteret om brugerens egen udviklingsproces hen imod at leve et meningsfuldt liv, uagtet om der objektivt set stadig er tale om sygdom?

International forskning i tværfaglighed og samarbejde i psykiatrien anlægger selvsamme professionsorienterede perspektiv. Colombo m.fl. (2003) viser f.eks., hvordan 
forskellige faggrupper i det tværfaglige samarbejde i distriktspsykiatrien trækker på meget forskellige modeller for psykiatrisk sygdom og behandling, og at de forskellige modeller særligt konkurrerer med den biomedicinske model om autoritet og anerkendelse. Ligeledes viser Griffiths (1997) i sit studie af tværfaglighed i distriktspsykiatrien i Wales, at den biomedicinske model dominerer over f.eks. psykosociale forståelser af patienterne. I forhold til tværfaglighed og samarbejde i sundhedssystemet generelt fremhæver Hall (2005) faggruppernes silotænkning og kulturelle forskelle som afgørende barrierer for et godt samarbejde på tværs. Hun beskriver, hvordan faggrupper på sundhedsområdet konkurrerer om at udvide deres autoritet og dermed gøre sig uundværlige i behandlingen af patienterne. Denne konkurrence fører til, at faggrupperne udvikler deres helt egne 'cognitive maps' bestående af særegne arbejdsværdier, tilgange til problemløsning, sprog og professionelle værktøjer. F.eks. er lægerne vant til at arbejde selvstændigt og tage beslutninger om patienten uden at konferere med andre, mens socialfaglige medarbejdere ofte arbejder sammen i mindre teams og derfor er trænet $\mathrm{i}$ at løse problemerne sammen med andre (Hall, 2005; Reese \& Sontag 2001). Men da faggrupperne ikke udvikler indsigt i andre faggruppers 'cognitive maps', bliver samarbejde på tværs rigtig svært. Reese og Sontag (2001) fremhæver ydermere, at det tværfaglige samarbejde på et hospice besværliggøres af, at faggrupperne mangler viden om hinandens ekspertise, kompetencer, uddannelse, værdier og teoretiske fundament, hvilket fører til modstand blandt faggrupperne mod at inkludere hinanden i arbejdet med patienterne.

Der er ingen tvivl om, at professionsperspektivet har skabt værdifuld indsigt i den specifikke problematik, der opleves omkring sektorsamarbejdet i den danske psy- kiatri, og også mere generelt i forhold til de faldgruber, der kan opstå, når man sætter forskellige fagligheder sammen for at samarbejde. Det som professionsperspektivet tydeliggør er, at man inden for en given profession deler særlige værdier, verdensbilleder, kompetencer, viden og sprog, og så længe man primært opererer inden for sin egen professionelle silo, behøver man ikke reflektere nærmer over, hvordan man forstår de situationer, relationer og roller, man møder i det daglige arbejde. Kommunikationen mellem medarbejdere kan derfor basere sig på implicitte og uudtalte forståelser, som er delte, fordi man har samme professionelle baggrund - samme 'cognitive map'. Men med de ændrede organisationsformer inden for særligt den offentlige sektor, hvor det forventes, at der samarbejdes om kerneopgaven på tværs af faggrupper, organisationer og sektorer, vil man som professionel i langt højere grad opleve, at man i det daglige arbejde møder og skal forholde sig til samarbejdspartnere fra andre professioner. Det er derfor ifølge internationale professionsforskere (Dent \& Whitehead 2002; Noordegraaf 2007) nødvendigt at genfortolke vores forståelse af, hvad professionalisme er, og ikke længere primært se det som noget, der knytter folk sammen i forhold til værdier, verdensbilleder, viden og sprog. I stedet skal vi se den professionelle som refleksiv, meningsskabende og kommunikerende, og som en har brug for at gøre sig forståelig overfor samarbejdspartnere med andre professionelle baggrunde. Noordegraaf (2007) skriver således:

"Attempts to reinterpret professionalism... try to turn professionalism into a much more relational concept. Link with outside worlds, organizational rationales, and other professionals become essential parts of professionalism.... In a more practical sense, 
this calls for interdisciplinary knowledge and interactive skills" (s. 774-775).

I tråd med nyere professionsforsknings fokus på meningsskabelse, kommunikation og refleksivitet ønsker vi i denne artikel at anlægge et organiseringsperspektiv på fænomenet tværfaglighed og samarbejde. Med et organiseringsperspektiv mener vi, at vi ser på, hvordan aktørerne i forskellige behandlings- og socialpsykiatriske organisationer handler overfor hinanden, og hvordan dette er i overensstemmelse med den mening, de skaber om hinanden og om samarbejdet på tværs. Hvad trækker de på, når de skaber mening? Er der nogle forestillinger om samarbejdet, egen indsats og 'den anden', som aktørerne trækker mere på end andre? I så fald; hvad er det for en orden, der organiserer aktørernes handlinger i samarbejdet på tværs af de to sektorer? Da vores fokus i denne artikel er på sammenhængen mellem den mening, aktørerne skaber i samarbejdet mellem behandlings- og socialpsykiatrien og om hinanden, og deres handlinger, dvs. deres håndtering af de samarbejdsproblemer de oplever, anvender vi Karl Weicks teori (1995; 2001) om 'sensemaking' i organisationer. Vi anvender teorien til at analysere empirien fra en kvalitativ interviewundersøgelse for at besvare spørgsmålet: Hvordan oplever og håndterer forskellige faggrupper samarbejdsproblemer mellem behandlingspsykiatriske hospitalsenheder og socialpsykiatriske botilbud og centre? Det er med afsæt i teorien om sensemaking, at vi ønsker at forklare faggruppernes handlinger i det tværfaglige, tværorganisatoriske, tværsektorielle samarbejde, for dermed at finde frem til den orden i de tværgående relationer, der organiserer samarbejdet på tværs, dvs. producerer samarbejdsproblemerne.

Hvor ovenævnte forskning om det tværgående sektorsamarbejde fokuserer på kulturelle barrierer og professionskampe, ønsker vi at supplere og bidrage til denne litteratur ved at se på de indbyrdes relationer og interaktionsdynamikker, der skaber samarbejdsproblemerne, og som er at finde på frontmedarbejderniveau mellem behandlings- og socialpsykiatriske organisationer, som skal samarbejde med hinanden. Ved at analysere og forstå de dynamikker, der udspiller sig i medarbejdernes indbyrdes relationer, når de skal samarbejde og koordinere patientforløb, opnår vi indsigt i, hvordan man kan forstå deres praksis for samarbejde. Vi har valgt Weicks teori for på mikroniveau at undersøge, hvad, i form af meningsskabelser, faggrupperne 'enacter', når der opstår problemer i samarbejdet mellem behandlings- og socialpsykiatrien, og hvordan ovennævnte makrostrukturer af samarbejdsproblemer og relationer mellem behandlings- og socialpsykiatrien skabes og opretholdes af faggruppernes lokale meningsskabelse og enactments.

\section{Den danske psykiatri}

Den psykiatriske institution har udviklet sig. Først fra at være anstalter for sindssyge til det moderne psykiatriske hospital, og senere i 1980'erne med opsplitningen af det psykiatriske system. Her forblev det behandlingspsykiatriske område kædet sammen med det somatiske hospitalsvæsen, mens en mere decentral psykiatri, hvor brugerne får støtte på bosteder eller i egen bolig, skød frem. Især nedskæringen af sengepladser var med til at fremme indførslen af disse nye decentrale former for organisering i psykiatrien (Kelstrup 1983), hvor formålet var at yde støtte og behandling til mennesker med psykiske lidelser i en mere hjemlig atmosfære. I dag hører de behandlingspsykiatriske hospitalsenheder under regionerne, mens de socialpsykiatriske bosteder og centre hører under kommunerne. 
Behandlingspsykiatrien omfatter åbne og lukkede hospitalsafdelinger, ambulante klinikker samt opsøgende teams, som diagnosticerer og tilbyder medicinsk behandling af personer, der lider af psykisk sygdom (Johansen m.fl. 2012). Medarbejdere i behandlingspsykiatrien har derfor typisk en medicinsk uddannelse som psykiatere, sygeplejersker eller social- og sundhedsassistenter. I behandlingspsykiatrien er den medicinske model og begrebet 'sygdom' i fokus, og det handler om at behandle patienternes underliggende patologier for derigennem at rette op på ubalancer (Cockerham 1992; Eplov m.fl. 2010). Behandlingspsykiatrien har oplevet store omorganiseringer i de seneste årtier med mange nedlagte sengepladser og kortere indlæggelsestid. Kerneopgaven for medarbejderne i den moderne hospitalspsykiatri har derfor ændret sig til primært at yde patienterne stabiliserende medicinsk behandling via korte indlæggelser, hvorefter patienterne forventes at blive samlet op og viderebehandlet af de ambulante tilbud i socialpsykiatrien (Madsen m.fl. 2011).

Socialpsykiatrien omfatter botilbud, væresteder for psykisk syge og kommunale støtte-kontaktpersoner, der udøver støtte til sindslidende, der bor i eget hjem (Johansen m.fl. 2012). Det er primært pædagoger, ergoterapeuter, socialrådgivere, psykologer og social- og sundhedsassistenter, der arbejder i socialpsykiatrien. I socialpsykiatrien lægges der primært vægt på en psykosocial tilgang til mental sundhed, frem for diagnoser og medicinsk behandling. Den psykosociale tilgang lægger vægt på borgerens rettigheder og giver dem en aktiv rolle i deres egen helbredelse i stedet for kun at fokusere på sygdommen (Anthony 1993). Kerneopgaven for medarbejderne i socialpsykiatrien er derfor at yde borgerne socialpoedagogisk støtte, så de med tiden kan blive 'hverdagsduelige', dvs. i stand til at leve en selvstændig tilværelse, også selvom de stadig er syge.

Medarbejdergrupperne i behandlingsog socialpsykiatrien har altså forskellige kerneopgaver. Derudover har de også meget forskellige tidsorganiseringer for deres arbejde. Hvor hospitalspsykiatrien, som er de behandlingspsykiatriske organisationer, vi har med i vores undersøgelse, typisk opererer med meget korte, stabiliserende indlæggelser, har socialpsykiatriens bosteder og kommunale hjemmevejlederteams mulighed for at yde en mere langsigtet pædagogisk og socialfaglig indsats over for de sindslidende.

Vi kan altså konstatere, at de har forskellige kerneopgaver og forskellige tidsorganiseringer i behandlings- og socialpsykiatrien. Dette ændrer dog ikke ved, at mange sindslidende har brug for støtte fra både behandlings- og socialpsykiatrien på forskellige tidspunkter i deres støtte- og behandlingsforløb. Dette betyder, at det ikke giver mening udelukkende at have blik for de organisatorisk definerede kerneopgaver, der skal løftes i hver af de to psykiatriske systemer. De sindslidende er afhængige af, at deres behandlings- og støtteforløb, som ofte rummer ydelser fra begge sektorer, bliver koordineret mellem medarbejdere fra både de psykiatriske hospitalsafdelinger samt socialpsykiatriske organisationer. Et fokus på psykiatriens opgaveløsning bør derfor sætte brugerne i centrum (Kjær \& Pedersen 2010). I casen, som præsenteres i denne artikel, oplever medarbejdere i både behandlings- og socialpsykiatrien, at der er alvorlige problemer med samarbejdet mellem faggrupper fra organisationer på tværs af de psykiatriske sektorer. Alle de interviewede reflekterer over, hvordan problemerne i samarbejdet har betydning for brugernes oplevelser af at modtage behandling og støtte i psykiatrien. 


\section{Meningsskabelse i samarbejdsproblemer}

Karl Weicks teori om 'sensemaking' i organisationer har en procesorienteret, konstruktivistisk tilgang til skabelsen af mening og handler således ikke om at have en mening om noget, men om at give mening til noget. Det betyder, at det er ved at placere dette 'noget' i en sammenhæng, at der skabes forståelse om hændelser, ting og situationer. På den måde sker meningsskabelse hele tiden, fordi folk retrospektivt skaber mening i situationer, de befinder sig i. Weick skriver om processer for meningsskabelse: "Active agents construct sensible, sensable events. They structure the unknown" (1995: 4). Meningsskabelse som procesteori handler om perception, fortolkning og handling, som kontinuerligt forekommer og revideres cyklisk (Weick 1979). To grundlæggende antagelser ligger til grund for Weicks teori om meningsskabelse. Den første antagelse er, at skabelsen af mening aldrig sker $i$ et socialt tomrum. Meningsskabelse er en social proces, hvor sociale konstruktioner af mening sker gennem social interaktion. Relationer mellem menneskerne er således centrale i skabelsen af mening. Med denne antagelse har Weicks teori således flyttet det forskningsmæssige fokus på fortolkning og mening væk fra individet og ind i organisationen (Mills m.fl. 2010). Studier af meningsskabelse har af samme grund et stort fokus på tale og diskurs, fordi det er herigennem, at meget social kontakt bliver medieret (Weick 1995).

Den anden grundlæggende antagelse i Weicks teori om meningsskabelse er, at tænkning og handling definerer hinanden (Weick m.fl. 2005). Dette betyder, at skabelsen af mening er tæt knyttet til det at handle: På den ene side er individet medskaber af sine omgivelser, når det skaber mening, og på den anden side er handling en betingelse for meningsskabelsen. Weick tager af- stand fra en forståelse af omgivelserne som en objektiv størrelse, der er derude. I stedet ser han individer som aktive medskabere af omgivelserne (Weick 1993). Begrebet 'enactment' beskriver en gensidig proces, hvori omgivelserne påvirker individet, og individet påvirker omgivelserne. Dermed søger begrebet 'enactment' at indfange, at folk er med til at skabe deres omgivelser, fordi de handler i overensstemmelse med, hvordan de ser verden - deres meningsskabelse (Murphy 2015). Fra dette perspektiv handler meningsskabelse således ikke kun om at fortolke verden, men lige så meget om at skabe den.

I denne artikel anvender vi sensemaking perspektivet til at undersøge, hvordan faggrupperne i psykiatrien oplever og håndterer samarbejdsproblemer mellem behandlingspsykiatriske hospitalsenheder og socialpsykiatriske botilbud og centre. Vi tager dermed afstand fra samarbejdsproblemer som objektive størrelser, der er 'derude', for selvom Weick anerkender, at makrostrukturer eksisterer, er hans ærinde primært at undersøge på mikroniveau, hvordan disse strukturer sætter sig igennem i den lokale meningsskabelse. Weick ophæver således dikotomien mellem mikro- og makroniveau, da han ser dem som gensidigt konstituerende (Weick 1993). Makrostrukturer eksisterer ikke uafhængigt af reproduktion i konkrete interaktioner på mikroniveau. Det er netop igennem den lokale meningsskabelse og 'enactement', at strukturer på makroniveau skabes og opretholdes. Analysen af meningsskabelse i samarbejdsproblemer viser med tydelighed, at medarbejderne på forskellig vis konstruerer de problemer, de oplever i samarbejdet mellem behandlings- og socialpsykiatriske organisationer. Denne forskellighed har stor betydning for, hvordan samarbejdsproblemerne kan gribes an. 


\section{Metode}

Da den såkaldte paradigmekamp siges at finde sted mellem social- og behandlingspsykiatrien, indsamlede vi empirien inden for begge disse sektorer. I 2011-2012 gennemførte vi en større interviewundersøgelse bestående af 20 enkeltinterviews og tre gruppeinterviews med 14 medarbejdere fra psykiatrien (se tabel 1). Samlet set har vi interviewet 34 medarbejdere. Fra behandlingspsykiatrien interviewede vi psykiatere, sygeplejersker og social- og sundhedsassistenter fra to lukkede psykiatriske hospitalsafdelinger og en psykiatrisk skadestue. Fra socialpsykiatrien interviewede vi pædagoger, psykologer og ledere fra to botilbud og pædagogisk uddannede støtte-kontaktpersoner, også kaldet hjemmevejledere, fra to kommunale centre. Interviewpersonerne arbejder i organisationer, der ligger inden for samme geografiske område. De har samarbejdsflader med hinanden om de samme brugere på tværs af sektorerne og er således en del af det samme inter-organisatoriske felt. Samarbejdet mellem behandlings- og socialpsykiatriske organisationer er synligt igennem brugerne, da det er brugerne, der bevæger sig - eller bevæges - mellem de psykiatriske organisationer for at få hjælp.

For at få indblik i relationer og interaktioner mellem frontmedarbejdere i de forskellige behandlings- og socialpsykiatriske organisationer opfordrede vi alle interviewpersonerne til at fortælle om situationer, hvor de havde oplevet samarbejdsproblemer med organisationer på tværs af de to psykiatriske systemer. Da vi går fænomenologisk (Moustakas 1994; Schutz 1970) til værks i vores undersøgelse, betyder det, at vi undersøger faggruppernes oplevede livsverden og

Tabel 1: Interviewpersoner

\begin{tabular}{|c|c|c|c|c|c|}
\hline $\begin{array}{l}\text { Interviewper- } \\
\text { son nr. }\end{array}$ & Ansættelse & $\begin{array}{l}\text { Organisatorisk } \\
\text { niveau }\end{array}$ & Organisation & Psykiatrisk system & Interviewform \\
\hline 1. & Pædagog & medarbejder & bosted $A$ & socialpsykiatrien & enkelt \\
\hline 2. & Pædagog & medarbejder & bosted $A$ & socialpsykiatrien & enkelt \\
\hline 3. & Pædagog & medarbejder & bosted $\mathrm{A}$ & socialpsykiatrien & enkelt \\
\hline 4. & Pædagog & medarbejder & bosted $\mathrm{A}$ & socialpsykiatrien & enkelt \\
\hline 5. & Pædagog & medarbejder & bosted $A$ & socialpsykiatrien & enkelt \\
\hline 6. & Pædagog & medarbejder & bosted $A$ & socialpsykiatrien & enkelt \\
\hline 7. & Sygeplejerske & medarbejder & $\begin{array}{l}\text { lukket psykiatrisk } \\
\text { afdeling A }\end{array}$ & behandlingspsykiatrien & enkelt \\
\hline 8. & Sygeplejerske & medarbejder & $\begin{array}{l}\text { lukket psykiatrisk } \\
\text { afdeling A }\end{array}$ & behandlingspsykiatrien & enkelt \\
\hline 9. & Sygeplejerske & leder & $\begin{array}{l}\text { lukket psykiatrisk } \\
\text { afdeling A }\end{array}$ & behandlingspsykiatrien & enkelt \\
\hline 10. & $\begin{array}{l}\text { Social og sund- } \\
\text { hedsassistent }\end{array}$ & medarbejder & $\begin{array}{l}\text { lukket psykiatrisk } \\
\text { afdeling A }\end{array}$ & behandlingspsykiatrien & enkelt \\
\hline 11. & Psykiater & leder & $\begin{array}{l}\text { lukket psykiatrisk } \\
\text { afdeling A }\end{array}$ & behandlingspsykiatrien & enkelt \\
\hline
\end{tabular}




\begin{tabular}{|c|c|c|c|c|c|}
\hline 12. & $\begin{array}{l}\text { Social og sund- } \\
\text { hedsassistent }\end{array}$ & medarbejder & $\begin{array}{l}\text { lukket psykiatrisk } \\
\text { afdeling A }\end{array}$ & behandlingspsykiatrien & enkelt \\
\hline 13. & $\begin{array}{l}\text { Social og sund- } \\
\text { hedsassistent }\end{array}$ & medarbejder & $\begin{array}{l}\text { lukket psykiatrisk } \\
\text { afdeling A }\end{array}$ & behandlingspsykiatrien & enkelt \\
\hline 14. & Psykiater & leder & $\begin{array}{l}\text { psykiatrisk ska- } \\
\text { destue }\end{array}$ & behandlingspsykiatrien & enkelt \\
\hline 15. & Sygeplejerske & medarbejder & $\begin{array}{l}\text { psykiatrisk ska- } \\
\text { destue }\end{array}$ & behandlingspsykiatrien & enkelt \\
\hline 16. & $\begin{array}{l}\text { Social og sund- } \\
\text { hedsassistent }\end{array}$ & medarbejder & $\begin{array}{l}\text { psykiatrisk ska- } \\
\text { destue }\end{array}$ & behandlingspsykiatrien & enkelt \\
\hline 17. & Sygeplejerske & medarbejder & $\begin{array}{l}\text { psykiatrisk ska- } \\
\text { destue }\end{array}$ & behandlingspsykiatrien & enkelt \\
\hline 18. & Leder af bosted & leder & bosted A & socialpsykiatrien & enkelt \\
\hline 19. & Sygeplejerske & medarbejder & $\begin{array}{l}\text { lukket psykiatrisk } \\
\text { afdeling B }\end{array}$ & behandlingspsykiatrien & enkelt \\
\hline 20. & Pædagog & medarbejder & bosted B & socialpsykiatrien & enkelt \\
\hline 21. & Psykolog & medarbejder & bosted A & socialpsykiatrien & gruppe \\
\hline 22. & Psykolog & medarbejder & bosted $A$ & socialpsykiatrien & gruppe \\
\hline 23. & Pædagog & medarbejder & bosted B & socialpsykiatrien & gruppe \\
\hline 24. & Pædagog & medarbejder & bosted B & socialpsykiatrien & gruppe \\
\hline 25. & Pædagog & medarbejder & bosted B & socialpsykiatrien & gruppe \\
\hline 26. & Hjemmevejleder & medarbejder & $\begin{array}{l}\text { kommunalt } \\
\text { center A }\end{array}$ & socialpsykiatrien & gruppe \\
\hline 27. & Hjemmevejleder & medarbejder & $\begin{array}{l}\text { kommunalt } \\
\text { center A }\end{array}$ & socialpsykiatrien & gruppe \\
\hline 28. & Hjemmevejleder & medarbejder & $\begin{array}{l}\text { kommunalt } \\
\text { center B }\end{array}$ & socialpsykiatrien & gruppe \\
\hline 29. & Sygeplejerske & medarbejder & $\begin{array}{l}\text { lukket psykiatrisk } \\
\text { afdeling B }\end{array}$ & behandlingspsykiatrien & gruppe \\
\hline 30. & Sygeplejerske & medarbejder & $\begin{array}{l}\text { lukket psykiatrisk } \\
\text { afdeling B }\end{array}$ & behandlingspsykiatrien & gruppe \\
\hline 31. & Sygeplejerske & medarbejder & $\begin{array}{l}\text { lukket psykiatrisk } \\
\text { afdeling B }\end{array}$ & behandlingspsykiatrien & gruppe \\
\hline 32. & Sygeplejerske & medarbejder & $\begin{array}{l}\text { lukket psykiatrisk } \\
\text { afdeling A }\end{array}$ & behandlingspsykiatrien & gruppe \\
\hline 33. & Sygeplejerske & medarbejder & $\begin{array}{l}\text { lukket psykiatrisk } \\
\text { afdeling A }\end{array}$ & behandlingspsykiatrien & gruppe \\
\hline 34. & Sygeplejerske & medarbejder & $\begin{array}{l}\text { psykiatrisk ska- } \\
\text { destue }\end{array}$ & behandlingspsykiatrien & gruppe \\
\hline
\end{tabular}


dagligdagsforståelse af, hvad samarbejdsproblemerne består i, og hvorfor de opstår. Ved at få interviewpersonerne til at fortælle om konkrete situationer, hvor de oplevede samarbejdsproblemer med faggrupper fra 'det andet' psykiatriske system, forsøger vi at indfange, hvad det er, der handles til live og konstituerer samarbejdsproblemer i psykiatrien.

Vi anvendte en tematisk analysemetode (Braun \& Clarke 2006) til vores systematiske bearbejdning af empirien, da denne metode er velegnet til at identificere og analysere temaer og mønstre i empirisk materiale. Alle interviews er transskriberet og kodet induktivt, således at det er interviewpersonernes beskrivelser, der har defineret, hvilke temaer inden for samarbejdsproblemer, der er særlig relevante i det daglige arbejde i psykiatrien. Interviewene er blevet kodet ud fra de problemstillinger, som medarbejderne har lagt særlig vægt på. Vi foretog følgende trin i dataanalysen: Først gennemlæste vi alle interviewudskrifter for at få indtryk af så mange temaer og mønstre som muligt i forhold til problemer i samarbejdet mellem organisationer i psykiatrien omkring de sindslidendes behandlings- og støtteforløb. Dernæst kodede vi interviewudskrifter og fandt en række forskellige oplevelser med samarbejdsproblemer: hvad de handler om, og i hvilke situationer de opstår. Endelig inddelte vi de forskellige fortolkninger i fem forskellige hovedtemaer om, hvad samarbejdsproblemer handler om for de faggrupper, der arbejder i psykiatrien. En note om brugen af ord i denne artikel: Medarbejdere i behandlingspsykiatrien omtaler de sindslidende som 'patienter', mens medarbejdere i socialpsykiatrien omtaler dem som 'beboere' på bosteder eller 'borgere'. For ikke at tage parti anvender vi ordet 'brugere' om de mennesker, der har brug for behandling og støtte fra psykiatriske organisationer.

\section{Meningsskabelse og enactment i problemer i det tværfaglige, tværorganisatoriske, tværsektorielle samarbejde i psykiatrien}

Med udviklingen i hospitalspsykiatrien, i form af nedlagte sengepladser og accelererede behandlingsforløb, bliver mennesker med alvorlige psykiatriske lidelser i dag udskrevet fra hospitalspsykiatrien langt hurtigere end tidligere, hvorfor det er helt afgørende, at medarbejdere i de to sektorer koordinerer den enkelte brugers støtte- og behandlingsforløb. Mange brugere er simpelthen lang mere syge end tidligere, når de udskrives, hvorfor de kommunale tilbud i socialpsykiatrien spiller en central rolle i forhold til at yde brugerne støtte til hverdagen og til opfølgende behandling. De kommunale støtte-kontaktpersoner støtter brugere, der bor i eget hjem, mens brugere, der bor på et bosted, modtager støtte fra bostedets medarbejdere.

Flere af de interviewede oplever dog, at der er alvorlige problemer i samarbejdet mellem behandlings- og socialpsykiatriske organisationer. Selvom medarbejderne i behandlings- og socialpsykiatrien samarbejder om en fælles gruppe af brugere, oplever de ikke nødvendigvis de samme problemer i samarbejdet mellem dem. Som vi viser nedenfor, kan de fremstå enige om, at der inden for et bestemt område overordnet set er nogle problemer i samarbejdet, men problemerne opleves forskelligt og har forskellig relevans for deres arbejde. Et område, hvor medarbejdere i både behandlings- og socialpsykiatrien ofte oplever problemer i samarbejdet, er når informationer om brugernes behandlings- og støtteforløb ikke udveksles mellem organisationer ved indlæggelse, under indlæggelse samt ved udskrivning. 


\section{Manglende udveksling af information}

Medarbejderne i socialpsykiatrien beskriver, at mange brugere oplever et kaotisk udskrivningsforløb fra de psykiatriske hospitalsafdelinger, fordi viden om brugernes behandling aldrig formidles videre til socialpsykiatrien. Brugerne udskrives ofte fra hospitalet uden at medarbejderne i socialpsykiatrien informeres eller inviteres til udskrivningskonference. Medarbejderne påpeger, at vigtig information, vedrørende brugerens indlæggelsesforløb samt planer om opfølgende behandling, går tabt. Ligeledes oplever de, at de ikke bliver informeret om ændringer i brugernes medicin, hvilket gør det svært for dem at følge op på brugernes behandling:

"Når borgeren kommer hjem fra indloeggelsen, aner vi ikke, om der er aendret $i$ medicinen, hvad der er sket, eller hvad der skal ske" (pædagog på bosted, interviewprs. nr. 25).

Hjemmevejlederne i de kommunale centre oplever tilsvarende, at de ikke kontaktes, når brugere indlægges. Den manglende orientering er ofte til gene for hjemmevejledernes arbejde, fordi de bruger værdifulde ressourcer på at finde ud af, hvor brugeren befinder sig: "Det giver unødige problemer og spekulationer, og man tilkalder låsesmed og politi..." (hjemmevejleder, interviewprs. nr. 28). Den manglende udveksling af information begrænser således de socialpsykiatriske medarbejdere i deres arbejde med at støtte og følge op på brugernes behandling efter endt hospitalsindlæggelse.

Mens medarbejderne i socialpsykiatrien især oplever, at de ikke informeres ved indlæggelse og udskrivning, peger medarbejderne i behandlingspsykiatrien på, at der mangler kontakt til socialpsykiatriens medarbejdere under brugernes indlæggelse:
"Det er sjoeldent, at jeg oplever, at medarbejdere i socialpsykiatrien kommer meget under brugernes indloeggelser" (sygeplejerske på lukket hospitalsafdeling, interviewprs. nr. 9).

Når de socialpsykiatriske medarbejdere ikke besøger brugeren under indlæggelsen, ved de ikke, hvad der er foregået under behandlingsforløbet, og de behandlingspsykiatriske medarbejdere peger på, at i disse situationer kan brugerne komme til at føle sig svigtet af deres støtteperson, hvormed det bliver sværere for støttepersonen at støtte og motivere brugerne til at tage deres medicin efter hospitalsindlæggelsen. Medarbejderne i behandlingspsykiatrien oplever derfor ofte, at det er med et skælvende hjerte, at de udskriver brugerne:

"Når vi slipper dem fra afdelingen, så er der ikke rigtig noget, indtil noeste gang de kommer ind" (sygeplejerske på lukket hospitalsafdeling, interviewprs. nr. 29).

Medarbejderne i behandlingspsykiatrien oplever, at de socialpsykiatriske medarbejdere ikke opsøger den information, der er relevant for at kunne udføre deres arbejde. F.eks. undlader de at deltage i udskrivningskonferencer, selvom de bliver inviteret:

"Når vores patienter har afsluttet behandlingen, og vi ringer til bostedet for at fortoelle, at patienten udskrives, siger de ofte, at de ikke har tid til at komme til et udskrivningsmøde for ugen efter. Men problemet er, at vi slet ikke kan planloegge så langt frem" (sygeplejerske på lukket hospitalsafdeling, interviewprs. nr. 30).

Konsekvenserne af dette fravær er, at vigtige oplysninger om behandlingen ofte går tabt, og de hospitalsansatte kobler dette fravær til, at mange brugere stopper med at tage 
deres medicin, så snart de forlader hospitalet, hvorefter mange hurtigt falder tilbage i den dårlige tilstand, de var i før indlæggelsen, og må genindlægges. Ifølge mange behandlingspsykiatriske medarbejdere kunne mange genindlæggelser undgås, hvis bare de socialpsykiatriske medarbejdere ville prioritere at få de oplysninger, der er tilgængelige om brugernes behandlingsforløb og opfølgende behandling.

Af ovenstående er det tydeligt, at både behandlings- og socialpsykiatriske medarbejdere oplever problemer i deres samarbejde om koordinering af brugernes behandlings- og støtteforløb. Fra et sensemaking-perspektiv vil vi gerne forstå, hvad det er for meningsskabelser, medarbejderne handler i forhold til, når de ikke udveksler informationer med hinanden. Hvad er det for forestillinger om samarbejdet og 'de andre', der handles til live i relationen mellem behandlingspsykiatrien og socialpsykiatrien? Vi vil altså forsøge at forklare deres manglende udveksling af information ved at analysere deres meningsskabelse. Vores opmærksomhed i resten af analysen er derfor på de meningsskabelser, der skaber dynamikkerne mellem grupperne i de to sektorer, som opleves som samarbejdsproblemer på mikroniveau og samtidig opretholder skellet mellem behandlingspsykiatrien og socialpsykiatrien på makroniveau.

I begge sektorer fremhæver medarbejderne, at problemerne med manglende udveksling af information om brugernes behandlings- og støtteforløb opstår, fordi de ikke forstår hinandens arbejdsopgaver og arbejdsområder. Medarbejderne fortæller, at der ofte opstår problemer, når medarbejdere fra 'den anden' sektor har urealistiske forventninger til deres arbejdsområde og mangler forståelse for de disponeringer, der foretages.

\section{Manglende forståelse for hinandens arbejde}

Medarbejderne i behandlingspsykiatrien oplever ofte, at socialpsykiatrien misforstår deres arbejdsvilkår, f.eks. ved at forvente, at brugerne kan forblive indlagt på hospitalsafdelingerne, indtil de er færdigbehandlede:

"De psykiatriske afdelinger er altid overbelagte, og vi er derfor ofte tvunget til at udskrive patienter op til weekenden, så der er plads til nye patienter" (sygeplejerske på lukket hospitalsafdeling, interviewprs. nr. 31).

Disse forventninger matcher dog ikke hospitalets primære opgave, som er at stabilisere brugerne ved hjælp af medicin og så hurtigt udskrive dem igen. De behandlingspsykiatriske afdelinger er hele tiden under pres i forhold til at få patienterne hurtigt igennem behandlingen, hvorfor hospitalspersonalet jævnligt må udskrive brugere, der stadig er meget sårbare. Derfor vælger personalet ofte at udskrive brugere, der bor på et bosted, fordi dér vil de i det mindste modtage opfølgende støtte fra bostedets personale. Medarbejderne i behandlingspsykiatrien argumenterer, at denne praksis sagtens kunne fungere, hvis de socialpsykiatriske medarbejdere blot ville gøre deres arbejde; holde brugerne under observation og sørge for, at de får deres medicin.

Medarbejderne i socialpsykiatrien oplever, at hospitalspersonalet ofte har urealistiske forventninger til den støtte, de kan yde brugere, der lige er blevet udskrevet fra hospitalet. Hvor socialpsykiatriens primære opgave er at yde støtte til brugerne, har hospitalspersonalet ofte forventninger om, at nyudskrevne brugere kan modtage sygefaglig pleje, og at bostederne kan fungere som minisygehuse: 
"De blev ved med at ringe til os for at få os til at måle blodtryk og puls, først på den ene beboer og dernoest den noeste, og så den noeste, og så sende målingerne til dem. Men er det ikke deres job? Jeg ved ikke, om de ikke tror, vi har noget at lave her, og at vi derfor lige så godt kan voere til rådighed til at udføre sygeplejefaglige opgaver" (pædagog på bosted, interviewprs. nr. 23).

Ifølge medarbejderne i socialpsykiatrien er problemet, at medarbejderne i behandlingspsykiatrien ofte udskriver de brugere, der bor på et bosted, selvom de stadig er meget sårbare, og så forventer, at brugerne vil modtage den tiltrækkelige opfølgende sygeplejefaglige hjælp fra bostedets medarbejdere:

"Vores beboere udskrives ofte alt for tidligt fra de psykiatriske hospitalsafdelinger, på trods af at vi hverken har normeringen, ressourcerne eller fagligheden til at kunne håndtere, når de er meget syge" (leder på bosted, interviewprs. nr. 18).

Andre eksempler der gives er, at personalet i behandlingspsykiatrien har forventninger om, at de socialpsykiatriske hjemmevejledere kan besøge nyudskrevne brugere dagligt, selvom der kun er ressourcer til et besøg om ugen. Mange brugere, der udskrives for tidligt, bliver som regel genindlagt, og mange ender som 'svingdørspatienter', der ryger ind og ud af de psykiatriske afdelinger, fordi de ikke færdigbehandles, fortæller mange medarbejdere i socialpsykiatrien. De forstår ikke, at behandlingspsykiatrien udskriver brugerne så hurtigt og ikke er villige til at genindlægge meget sårbare brugere. Medarbejderne i behandlingspsykiatrien forstår derimod ikke, at socialpsykiatrien ikke er villige til at løfte deres del af ansvaret, når patienterne udskrives. Deres urealistiske forventninger til hinandens arbejdsindsats og manglende forståelse for hinandens disponeringer fører til gensidige beskyldninger om, at man ikke gør sit arbejde godt nok, og i både behandlings- og socialpsykiatrien beskylder man således hinanden for at være årsagen til, at der er så mange svingdørspatienter.

I både behandlings- og socialpsykiatrien er de uindfriede forventninger til hinandens arbejdsindsats med til at skabe en række negative forestillinger om, hvordan faggrupperne i den anden sektor arbejder med brugerne. De negative forestillinger er med til at spænde ben for, at der kan opstå en ligeværdig og konstruktiv samarbejdsrelation mellem behandlings- og socialpsykiatrien.

\section{Negative forestillinger om hinandens arbejde}

I behandlingspsykiatrien fremstilles socialpsykiatrien ofte som inkompetent, fordi man mener, at de socialpsykiatriske medarbejdere ganske enkelt ikke besidder ikke den rette viden og de rette færdigheder, der skal til for at hjælpe og håndtere brugerne. Især formår medarbejderne i socialpsykiatrien ikke at a) motivere brugerne til at tage deres medicin, b) skabe en fast struktur, der støtter brugerne, c) nedtrappe konfliktsituationer med brugerne. De socialpsykiatriske medarbejdere fremstilles som særligt inkompetente, når det kommer til opgaven med at få brugerne til at tage deres medicin. En psykiater fortæller:

"Mit indtryk er, at de siger til patienten 'nu skal du lige have din medicin', og så siger patienten 'nej!', og så siger de bare 'okay', og så kommer man igen en halv time senere og håber, at de er mere motiverede. Jeg tror, der er et problem med måden, de kommer ind til patienterne $p a ̊$, når de forsøger at få dem til at tage deres medicin, og jeg tror, at mange genindloeggelser kunne undgås, hvis 
de var bedre til det" (psykiater på lukket hospitalsafdeling, interviewprs. nr. 11).

Ifølge medarbejderne i behandlingspsykiatrien mangler de i socialpsykiatrien en grundlæggende forståelse af psykisk sygdom, hvorfor de ikke ser medicinsk behandling som altafgørende i forhold til at lindre brugernes symptomer. Nogle hospitalsansatte beskylder endda ligefrem medarbejderne på bostederne for at tage medicinen fra brugerne, så snart de er udskrevet fra hospitalet:

"Vi har voeret ude for, at vi har velmedicineret en patient herfra, og lige så snart han kom til bostedet, blev alt medicinen taget fra ham. Og så stod han her igen, da der var gået en uge, og vi kunne starte forfra" (social og sundhedsassistent på lukket hospitalsafdeling, interviewprs. nr. 12).

I behandlingspsykiatrien ser man socialpsykiatriens manglende viden om psykiske lidelser som den primære årsag til de mange svingdørspatienter i psykiatrien.

Ligeledes formår de socialpsykiatriske medarbejdere heller ikke, ifølge medarbejderne i behandlingspsykiatrien, at skabe en fast struktur, der støtter brugerne:

"Til trods for at jeg er overloege i psykiatrien, så aner jeg ikke, hvad det er, de går og laver i socialpsykiatrien. Nogen gange fär man en patient ind af døren, hvor man toenker: 'hvad i alverden foregår der?' Nogle af de patienter vi fär ind fra bostedet ser jo ud som om, de kommer fra en koncentrationslejr" (psykiater på psykiatrisk skadestue, interviewprs. nr. 14).

Selvom ingen af de interviewede medarbejdere fra behandlingspsykiatrien nogensinde havde besøgt et bosted, har mange af dem alligevel den opfattelse, at særligt bostederne er præget af kaos, og at mange brugere er overladt til sig selv:

\begin{abstract}
"Nogle af de ting patienterne fortoeller derfra, altså, der er flere, der er døde af overdoser... Der foregår røverrier, slåskampe og massivt misbrug på det sted" (sygeplejerske på psykiatrisk skadestue, interviewprs. nr. 17).
\end{abstract}

De behandlingspsykiatriske medarbejdere forklarer, at mange brugere har brug for en fast struktur i deres hverdag for at føle sig trygge, men manglen på struktur på bostederne fører til, at beboerne tilbringer dagene med at drikke og tage narkotika inde på deres værelser, hvorefter de kommer op og slås med hinanden. Og er der noget medarbejderne i socialpsykiatrien ikke formår at håndtere, så er det slagsmål mellem brugerne:

"Det er de dårligste af de dårligste sindslidende, der bliver placeret derude. Og så har man en flok poedagoger til at tage sig af dem. Og alle ved jo, at poedagoger er sådan nogle, som mener, at psykose er en indloeringsproces" (sygeplejerske på lukket hospitalsafdeling, interviewprs. nr. 8).

I socialpsykiatrien skildres de medicinsk uddannede behandlingspsykiatriske medarbejdere ikke som inkompetente, men som værende ligeglade med brugerne. Dette er tydeligt, når brugerne a) fastholdes på høje doser af vanedannende medicin, b) underlægges tvang i behandlingen og c) udskrives tilfældigt fra de psykiatriske hospitalsafdelinger. Ifølge medarbejderne i socialpsykiatrien har de behandlingspsykiatriske medarbejde et meget snæversynet fokus på diagnoser og brugernes medicinering, og de er ligeglade med mennesket bag diagnosen, hvorfor de stort set aldrig ser medicinnedtrapning som en mulighed. I stedet holdes mange brugere fast i langva- 
rig medicinering, som er stærkt vanedannende, har en masse uheldige bivirkninger og er rigtig svært at komme ud af. Men det er det behandlingspsykiatriske personale tilsyneladende ligeglade med, fordi, som en pædagog på et bosted siger: "Mange brugere sidder fast i en form for kontrolleret misbrug af medicin" (interviewprs. nr. 3). Flere medarbejdere i socialpsykiatrien fortæller, at psykiaterne laver deres psykiatriske evalueringer på under fem minutter og aldrig besøger brugerne der, hvor de bor. De har derfor ingen chance for at vide, om en bruger får den rette dosis medicin, og deres manglende indsigt $\mathrm{i}$, hvordan medicinen påvirker brugernes i deres sociale liv, er, ifølge medarbejderne i socialpsykiatrien, grunden til, at det er svært at motivere brugerne til at tage deres medicin, når de udskrives fra det psykiatriske hospital.

Den negative fremstilling af behandlingspsykiatrien, som værende ligeglad med brugerne, næres yderligere af forestillinger om, at man i denne del af psykiatrien ofte vælger at anvende tvang i behandlingen af brugerne:

"Jeg hører aldrig vores beboere sige 'hold kaeft mand, den der indloeggelse var bare fed'. De bliver som regel sat op i medicin, og så bliver de jo ofte sat under tvang, mens de er derinde" (psykolog på bosted, interviewprs. nr. 22).

Derudover fremhæver de socialpsykiatriske medarbejdere, at personalet i behandlingspsykiatrien har en tilfældig tilgang til udskrivning af brugerne fra de psykiatriske afdelinger, da såkaldte 'prikkerunder' fredag eftermiddag kan afgøre, at en bruger pludseligt udskrives for at skabe plads til nye patienter i weekenden.

Medarbejderne i behandlingspsykiatrien fremstiller pædagogerne, der arbejder i socialpsykiatrien, som inkompetente, da de hverken har den rette viden eller de rette færdigheder til at hjælpe og håndtere brugerne, og medarbejderne i socialpsykiatrien fremstiller psykiaterne, sygeplejerskerne og social- og sundhedsassistenterne som ligeglade med brugerne, fordi de fastholder dem på høje doser af vanedannende medicin, anvender tvang og tilfældigt udskriver brugerne fra de psykiatriske hospitalsafdelinger. De negative forestillinger om hinandens arbejde fører til udbredt mistillid mellem faggrupperne i de to sektorer.

\section{Manglende tillid til hinandens arbejdsindsats}

I socialpsykiatrien enactes mistilliden ved, at man prøver at undgå behandlingspsykiatrien:

"Hvis en beboer har det virkelig skidt, så snakker vi med ham om, hvad vi kan gøre for at undgå, at han skal indloegges. For de ved jo godt, at det ikke er et rart sted at komme hen. Det er jo et sort hul, det sted" (pædagog på bosted, interviewprs. nr. 2).

For at minimere kontakten til behandlingspsykiatrien prøver man altså at undgå, at brugerne bliver indlagt på psykiatrisk afdeling. I behandlingspsykiatrien enactes mistilliden ved, at man forsøger at overtage de socialpsykiatriske opgaver i brugernes støtteforløb efter udskrivning fra hospitalet. Flere medarbejdere fra både behandlings- og socialpsykiatrien beretter om, at psykiatere på de psykiatriske hospitalsafdelinger kræver, at de opgaver, der normalt hører til de socialpsykiatriske medarbejderes ansvarsområde, i stedet varetages af en sundhedsuddannet medarbejder fra behandlingspsykiatrien. Mistilliden mellem faglighederne indikerer et alvorligt brist $i$ forholdet mellem behandlings- og socialpsykiatriske organisationer. 


\section{Ulighed mellem fagligheder}

I og med at medarbejderne i begge sektorer ikke har tillid til hinandens arbejdsindsats overfor brugerne, forsøger medarbejderne enten at undgå hinanden eller at overtage hinandens arbejdsopgaver. Men hvor de socialpsykiatriske medarbejderes undgåelsesadfærd kun forstærker de behandlingspsykiatriske forestillinger om dem som inkompetente, fører den behandlingspsykiatriske overtagelse af socialpsykiatriske arbejdsopgaver til en følelse af mindreværd hos de socialpsykiatriske medarbejdere. For dem etablerer disse dynamikker et internt magthierarki, hvor det socialpsykiatriske arbejde med - og viden om - brugerne ikke vægtes lige så højt som den behandlingspsykiatriske indsats:

"De føler sig som storebror i samarbejdsrelationen. Som dem, der har den nødvendige viden og uddannelse og faglighed" (hjemmevejleder, interviewprs. nr. 26).

I behandlingspsykiatrien ser man derimod sin faglighed som noget, der meget effektivt afhjælper symptomerne hos brugerne, da mange brugere, så snart de indlægges, hurtigt oplever at få det bedre. Tilsvarende ser man i behandlingspsykiatrien også sin faglighed som noget, der afhjælper de kvaler, som de socialpsykiatriske medarbejderes har med brugerne. Dette sker f.eks., når 'besværlige' brugere genindlægges, eller når brugere beholdes på hospitalsafdelingen i længere tid, end det strengt taget er nødvendigt i forhold til opgaven med at stabilisere patienterne:

"Vi ringer ofte til bostedet og siger 'vi vil egentlig gerne udskrive patienten', men så stejler bostedet som regel og siger 'jamen, jamen, jamen'. Og så tit og ofte så holder vi lidt på dem og toenker 'jamen vi kan da godt fungere som hotel og så optage pladsen for nogen, som måske har mere brug for det'” (sygeplejerske på lukket hospitalsafdeling, interviewprs. nr. 7).

I behandlingspsykiatrien ser man således sin faglighed som noget, der aflaster det socialpsykiatriske personale, der oplever store anstrengelser i deres arbejde med brugerne, fordi deres faglighed ikke har udrustet dem til at håndtere mennesker med svære sindslidelser.

\section{Diskussion og konklusion}

Ved at anlægge et organiseringsperspektiv og undersøge de faglige aktørers meningsskabelse og handlinger i de samarbejdsproblemer, de oplever mellem behandlings- og socialpsykiatriske organisationer, har vi i denne artikel forsøgt at gå i dybden med det, der skaber frustrationer hos medarbejderne. Alle de interviewede fortæller, at samarbejdsproblemerne handler om manglende udveksling af information og manglende koordinering af brugernes behandlings - og støtteforløb, hvilket yderligere forklares med, at medarbejderne på tværs af de to sektorer mangler forståelse for hinandens arbejde og derfor har urealistiske og uforløste forventninger til de indsatser, der kan tilbydes den enkelte bruger i 'den anden' sektor. De uforløste forventninger til hinandens arbejdsindsats fører til, at medarbejderne i begge lejre har en række negative forestillinger om hinandens fagligheder og hinandens måde at arbejde med brugerne på, hvorfor de alle nærer en nærmest grundlæggende mistillid til den arbejdsindsats, der udøves af medarbejderne i 'den anden' sektor. Mistilliden og de negative forestillinger indikerer en alvorlig brist i relationen mellem behandlings- og socialpsykiatriske fagligheder og organisationer, og skaber ulighed mellem faglighederne, hvor de socialfaglige medarbejdere i 
socialpsykiatrien oplever, at de ligger i bunden af hierarkiet.

Både medarbejdere i behandlings- og socialpsykiatrien oplever frustrationer pga. det konstante pres på ressourcer, og de mange brugere, der ikke får det bedre, men forbliver svingdørspatienter i årevis. Men i begge sektorer, håndterer medarbejderne deres frustrationer ved at anklage hinanden for at fejle i arbejdet med brugerne. De beskylder hinanden for uanstændig håndtering af brugerne, i form af hhv. omsorgssvigt og kaos på bostederne og kontrol og tvang på hospitalsafdelingerne, og de fremstiller hinandens syn på psykisk sygdom og arbejdsmetoder som forkerte og som årsagerne til, at mange brugere ikke får det bedre. Dette er i høj grad blevet en rutinepræget måde at tænke om problemerne på i samarbejdet og en rutinepræget måde at relatere til hinanden på på tværs af fagligheder, organisationer og sektorer i psykiatrien. Enkelte af de interviewede medarbejderne beskriver, hvordan de godt kan se, hvordan den rutineprægede sensemaking med negative forestillinger om 'de andre' virker som en selvopfyldende profeti. De negative forestillinger kommer til at overskygge de positive oplevelser, der også kan være, og kommer dermed til at modarbejde et godt samarbejde på tværs:

"Der er mange forestillinger om socialpsykiatriens manglende tilstedevoerelse, og at de ikke opsøger patienterne, selvom det er deres arbejde. Og så er kontakten jo allerede negativ, når kontaktpersonen kommer så ind af døren for at voere med $i$ et behandlingsforløb, fordi man på forhånd har en forestilling om, at 'I laver jo heller ikke noget', eller 'I gør det ikke godt nok, det I gør'" (sygeplejerske på lukket hospitalsafdeling, interviewprs. 19).
De negative forestillinger er med til at opretholde en grundlæggende mistillid til samarbejdspartneren, hvilket bremser samarbejdet. Med vores fokus ser vi, at det er igennem de faglige aktørers meningsskabelse og fastlåste handlerum, at strukturer på makroniveau omkring langvarige samarbejdsproblemer mellem de psykiatriske sektorer skabes og opretholdes. Som Weick skriver: "Sensemaking is the feedstock for institutionalization" (1995: 36). Med det mener han, at niveauerne for mikro- og makroniveau gensidigt skaber hinanden. Vi ser, at medarbejderne, igennem konkrete kommunikative interaktioner og handlinger, refererer til makrostrukturer, som f.eks. at psykisk sygdom er et medicinsk speciale og skal behandles med medicin, eller at brugeren har brug for støtte og omsorg for at kunne leve med sin sygdom. Man kunne dog sandsynligvis forvente, at et fokus på, hvordan det opleves for brugerne, at modtage kerneydelser i psykiatrien, ville kunne rumme, at man som bruger modtager forskellige ydelser på forskellige tidspunkter i ens støtte- og behandlingsforløb. Men i samarbejdet mellem faggrupper i de to sektorer fører de mange oplevelser med dårlig koordination og uforløste forventninger til hinandens indsats til, at der opstår alternative organiseringer. Man danner negative billeder, mister tilliden til hinanden og forsøger derfor at minimere kontakten til hinanden på tværs af organisationer eller overtage de arbejdsopgaver, som det ellers var meningen, at den anden sektor skulle stå for. Vi ønsker dermed at skabe opmærksomhed om, at forskellige faggrupper ikke bare ukritisk kan sættes sammen for at skulle samarbejde, og at forskellige faggrupper ikke bare kan forventes at skulle indgå som ligeværdige partnere og samarbejde på tværs.

Vores analyse af meningsskabelse i samarbejdsproblemer i psykiatrien har fokus 
på, hvordan samarbejdsproblemerne opleves og fremstilles lokalt i de psykiatriske organisationer, hvilket kan fortælle os noget om handlerummet for håndtering af samarbejdsproblemerne mellem organisationer. Forskellig meningsskabelse i samarbejdsproblemer handler således ikke bare om uenigheder om, hvordan den samarbejdende praksis mellem sektorer skal defineres, men i høj grad også om, hvem der har retten til at definere, hvad der er sandt i forhold til, hvad samarbejdsproblemerne handler om. I analysen viser vi, at trods den konstante indskrænkning af det behandlingspsykiatriske felt, ved blandt andet nedlagte sengepladser og korte hospitalsindlæggelser, holder lægerne og sygeplejerskerne fortsat fast i en position af, at det er dem, der besidder den primære faglige ekspertise i psykiatrisk sygdom og behandling. De socialpsykiatriske medarbejdere på bostederne og de kommunale støtte-kontaktpersoner forsøger aktivt at modarbejde medicinernes indflydelse på, hvordan deres arbejde skal vurderes.

På den måde aktualiserer denne artikels analyse af meningsskabelse i samarbejdsproblemer en kritik, der har været rejst af Weicks teori om meningsskabelse. Særligt Mills m.fl. (2010) og Landau og Drori (2008) har kritiseret Weick for at antage, at meningsskabelse er en demokratisk proces, hvori alle stemmer er lige vigtige, og at processer for meningsskabelse er rettet mod konsensusforståelse. Analysen af meningsskabelse i samarbejdsproblemer viser med tydelighed, at selvom både medarbejderne i behandlingspsykiatrien og i socialpsykiatrien oplever problemer i det tværgående samarbejde, skaber de ikke den samme mening om samarbejdsproblemerne. Hvor samarbejdsproblemer kan bestå af mere eller mindre tydelige sammenstød og stridigheder, skal disse ses som kulminationer i processer, som det meste af tiden hand- ler om modsatrettede forståelser af, hvad det er, der foregår i relationen mellem behandlingspsykiatrien og socialpsykiatrien. Ved at vise divergensen i meningsskabelse i samarbejdsproblemer afviser nærværende analyse den antagelse, der er i Weicks teori, som beskriver meningsskabelse som demokratisk og konsensussøgende.

Idéen med at organisere den offentlige sektor via samarbejde på tværs af fagligheder, organisationer og endda sektorer udspringer af, at man vil højne kvaliteten af den offentlige service, der tilbydes, men til lavere omkostninger. Som den internationale litteratur vi gennemgik i indledningen viser, er det ikke en unik dansk idé, at mere samarbejde om kerneopgaven på tværs af fagligheder, organisationer og sektorer skal være svaret på effektiviseringen af den offentlige sektor. Det er en udbredt måde, som moderne stater har valgt at organisere arbejdet på, med f.eks. alvorligt psykisk syge mennesker. I vores undersøgelse viser vi, hvilke relationelle dynamikker, der er i spil, når organiseringen af det tværfaglige, tværorganisatoriske og tværsektorielle samarbejde ikke fungerer. Det er i den forbindelse ofte professionsperspektivet, der trækkes frem for at forklare, hvorfor forskellige faggrupper kan have svært ved at samarbejde. Dette perspektiv har bidraget med vigtige indsigter $i$, at de professionelle i høj grad har deres særegne 'cognitive map', dvs. særegne værdier, verdensbilleder, kompetencer, viden, og sprog, som kan stå i direkte modsætning til andre professioners 'cognitive maps'. Men med de ændrede organisationsformer, hvor professionelle forventes at samarbejde om kerneopgaven på tværs af faggrupper, organisationer og sektorer, bliver det nødvendigt at anskue professionalisme, ikke kun som noget, der knytter folk sammen via deres 'cognitive map', men i høj grad som et mere relationelt fænomen, da professionelle har relationer til 
omverden og indgår i partnerskaber med individer og grupper med andre professionelle baggrunde (Noordegraaf 2007). Ifølge professionsperspektivet handler det i høj grad om at skabe en tradition for tværfaglighed allerede i uddannelsessystemet, hvis vi vil bryde de monofaglige monopoler og for alvor gøre nytte af, hvad det tværfaglige samarbejde kan tilbyde (Hall 2005). Den internationale forskning i tværfaglighed og samarbejde fremhæver ligeledes, at der skal langt mere fokus på kommunikation, viden om og respekt for andres fagligheder samt konfliktløsning, hvis samarbejde på tværs af faggrupper og organisationer skal lykkes (Hall 2005; Magnusson \& Lutzen 2009).

I vores undersøgelse har vi undersøgt de indbyrdes relationer og dynamikker, som er at finde mellem frontmedarbejderne i de forskellige behandlings- og socialpsykiatriske organisationer, som skal samarbejde med hinanden. Som vores analyse viser, så konstruerer de forskellige personalegrupper i de forskellige typer af psykiatriske organisationer problemerne i mellem dem forskelligt, hvorfor også løsningerne konstrueres forskelligt. Første skridt er dog at fokusere på aktørernes meningsskabelse i samarbejdsproblemerne, så vi får indsigt i de forskellige faggruppers forskellige måder at konstruere samarbejdsproblemerne på. Ved at forstå deres praksis for samarbejde får vi mulighed for at ændre den. Som Weick skriver: "An important implication of sensemaking is that, to change a group, one must change what is says and what its words mean" (Weick 1995, 108). Vi har vist, at der ikke er nogen fælles meningsskabelse af, hvad 'vi kan' tilsammen, dvs. hvad synergieffekterne er og kunne være af de forskellige perspektiver på brugernes behandlings- og støtteforløb - tværtimod. Den viden kan bruges til at udvide de behandlings- og socialpsykiatriske organisationers handlerum i det ellers ret fastlåste tværfaglige, tværor- ganisatoriske, tværsektorielle samarbejde i psykiatrien.

\section{Referencer}

Anthony, William (1993): Recovery from mental illness, i Psychosocial Rehabilitation Journal, 16, 4, 11-23

Bengtsson, Steen (2011): Danmark venter stadig på sin psykiatrireform: et rids af udviklingen de seneste årtieri, SFI-Det Nationale Forskningscenter for Velfærd

Braun, Virginia \& Victoria Clarke (2006): Using thematic analysis in psychology, i Qualitative Research in Psychology, 3, 2, 77-101

Cockerham, William (1992): Sociology of Mental Disorder, Englewood Cliffs NJ, Prentice-Hall

Colombo, Antony m.fl. (2003): Evaluating the influence of implicit models of mental disorder on processes of shared decision making within community-based multi-disciplinary teams, Social Science and Medicine, $56,7,1557-1570$

Dent, Mike \& Stephen Whitehead (2002): Configuring the 'new' professional. In Mike Dent \& Stephen Whitehead (eds.) Managing Professional Identities. Knowledge, Performativity and the 'new' Professional, London, Routledge, 1-16

Eplov, Lene m.fl. (2010): Rehabilitering $i$ et historisk perspektiv. Psykiatrisk og psykosocial rehabilitering - en recoveryorienteret tilgang, Copenhagen, Munksgaard

Griffiths, Lesley (1997): Accomplishing team: teamwork and categorisation in two community mental health teams, The Sociological Review, 45, 1, 59-78

Hall, Pippa (2005): Interprofessional teamwork: professional cultures as barriers, Journal of Interprofessional Care, 19, 1, 188-196

Holm-Petersen, Christina \& Martin Sandberg Buch (2014): Litteratur om ledelse af samarbejde på tvoers af sektorer i sundhedsvaesenet, KORA - Det Nationale Institut for Kommuners og Regioners Analyse og Forskning, København

Johansen, Kathrine, Jessica Larsen \& Ann 
Nielsen (2012): Tvoersektorielt samarbejde $i$ psykiatrien. Videns- og erfaringsopsamling, KORA - Det Nationale Institut for Kommuners og Regioners Analyse og Forskning, København

Kelstrup, Anders (1983): Galskab, psykiatri, galebevoegelse, København, Amalie - Galebevægelse blad

Kistrup, Morten m.fl. (2009): Sektorsamarbejde i psykiatrien, Ugeskrift for Loeger, 171, 48, 3514-3518

Kjær, Peter \& Anne Reff Pedersen (red.) (2010): Ledelse gennem patienten: nye styringsformer i sundhedsvoesenet, København, Handelshøjskolens Forlag

Landau, Dana \& Israel Drori (2008): Narratives as sensemaking accounts: The case of an R\&D laboratory. Journal of Organizational Change Management, 21, 6, 701-720

Madsen, Marie, Anne Hvenegaard \& Eskild Fredslund (2011): Opgaveudvikling på psykiatriområdet. Opgaver og udfordringer $i$ kommunerne i relation til borgere med psykiske problemstillinger, København, Dansk Sundhedsinstitut

Magnusson, Annabella \& Kim Lutzen (2009): Factors that influence collaboration between psychiatric care and CSSs: experiences of working together in the interest of persons with long-term mental illness living in the community, Scandinavian Journal of Caring Sciences, 23, 1, 140-145

Mills, Jean, Amy Thurlow \& Albert Mills (2010): Making sense of sensemaking: The critical sensemaking approach, Qualitative Research in Organizations and Management, 5, 2, 182-195

Mikkelsen, Elisabeth Naima m.fl. (2013): Cross sector problems of collaboration in psychiatry, Danish Medical Journal, 60, 9, A4707

Moustakas, Clark (1994): Phenomenological Research Methods, USA, Sage Publications

Murphy, Tine (2015): Sensemaking. Introduktion til Karl Weick, København, Hans Reitzels Forlag

Noordegraaf, Mirko (2007): From "pure" to "hybrid" professionalism: Present-day professionalism in ambiguous public domains, Administration and Society, 39, 6, 761-785
Reese, Dona \& Mary-Ann Sontag (2001): Successful interprofessional collaboration on the hospice team, Health Social Work, 26, 3, 167-175

Region Hovenstaden (2010): Sundhedsaftale for Region Hovedstaden 2011-2014

Region Hovenstaden (2014): Sundhedsaftale 2015-2018. Region Hovedstaden og kommunerne i regionen

Rådgivende Sociologer (2012): Tvoersektorielle overgange i psykiatrien. Afrapportering af kvantitativ og kvalitativ undersøgelse, København, Rådgivende Sociologer ApS

Schutz, Alfred (1970): Interpretative sociology, i Helmut Wagner (ed.): Alfred Schutz on Phenomenology and Social Relations: Selected Writings, Chicago, University of Chicago Press, 265-93

Seemann, Janne, Jørgen Ærthøj \& Helle Rasmussen (2012): Sygehusenes truende selvtilstrækkelighed, i Danske Regioner, Dansk Selskab for ledelse i Sundhedsvæsenet: Sund ledelse: 19 Bud På God Sygehusledelse, København, Djøf/Jurist- og Økonomforbundet, 62-73

Weick, Karl (1979): The Social Psychology of Organizing, Massachusets, Addison-Wesley Pub.

Weick, Karl (1993): Sensemaking in organizations: Small structures with large consequences, in Murnighan, Keith (ed.): Social psychology in organizations: Advances in theory and research, New Jersey, Prentice-Hall Inc, 10-37

Weick, Karl (1995): Sensemaking in Organizations, London, Sage Publications

Weick, Karl (2001): Making Sense of the Organization, USA, Blackwell Publishing

Weick Karl, Kathleen Sutcliffe \& David Obstfeld (2005): Organizing and the process of sensemaking, Organization Science, 16, 4, 409-421 
Elisabeth Naima Mikkelsen, Ph.d., Adjunkt, Institut for Organisation, Copenhagen Business School, e-mail: enm.ioa@cbs.dk

Anne Petersen, Ph.d., Projektleder, KORA, Det Nationale Institut for Kommuners og Regioners Analyse og Forskning, e-mail: anpe@kora.dk

Anne Reff Pedersen, Ph.d., Lektor, Institut for Organisation, Copenhagen Business School, e-mail: arp.ioa@cbs.dk 